\title{
Quando "restos mortais" tornam-se rastros: algumas reflexões sobre a organização do Fundo Alice Piffer Canabrava do Arquivo do IEB/USP
}

\author{
[ When "mortal remains" become traces: some reflections about the \\ organization of the Alice Piffer Canabrava's Fund of IEB/USP's Archive
}

\section{Otávio Erbereli Júnior}

Agradeço a Luciana Suarez Galvão (IEB/USP) o convite para publicação.

\begin{abstract}
RESUMO - Este artigo é resultado de uma operação arquivística na qual fazer, sentir e refletir se entrelaçam. Durante os anos de 2015 e 20I6, o autor teve contato diário com a documentação de Alice Piffer Canabrava. Em um primeiro momento, narra-se a operação arquivística relacionada ao tratamento da documentação. O segundo momento é fruto de um fazer-sentir a partir desse contato íntimo e diário com a documentação, ou seja, traz algumas reflexões sobre as práticas de autoarquivamento empreendidas por Canabrava. PALAVRAS-CHAVE - Alice Piffer Canabrava; arquivística; arquivos pessoais.
\end{abstract}

\begin{abstract}
- ABSTRACT - This article is the result of an archivistic operation in which making, feeling and reflecting are intertwined. During 2015 and 20I6, the author had daily contact with Alice Piffer Canabrava's documentation. At first, the archivistic operation related to the handling of documentation is narrated. The second moment is the result of a makingfeel from this intimate and daily contact with the documentation, that is, it brings some reflections on the self-archiving practices undertaken by Canabrava. - KEYWORDS . Alice Piffer Canabrava; archivistic; personal archives.
\end{abstract}

Recebido em $I^{\circ}$ de agosto de $202 I$

Aprovado em 6 de setembro de $202 I$

ERBERELI JÚNIOR, Otávio. Quando “restos mortais” tornam-se rastros: algumas reflexões sobre a organização do Fundo Alice Piffer Canabrava do Arquivo do IEB/USP. Revista do Instituto de Estudos Brasileiros, Brasil, n. 80, p. I96-218, dez. 2021.

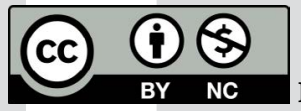

DOI: https://doi.org/Io.II6o6/issn.23I6-90IX.vIi8opI96-2I8

I Universidade de São Paulo (USP, São Paulo, SP, Brasil). 
Antes de conduzir a leitora e o leitor pelo Fundo Alice Piffer Canabrava gostaria de apresentar, rapidamente, a trajetória da titular e sua relação com o Instituto de Estudos Brasileiros da Universidade de São Paulo (IEB/USP).

Canabrava formou-se na Escola Normal Caetano de Campos, na Praça da República, em São Paulo, em I930, tendo recebido o diploma de "habilitação para o magistério público em São Paulo" e o Prêmio Barão do Rio Branco para o aluno com as maiores notas em história e geografia no decorrer dos cinco anos de curso. Foi professora do curso primário entre I93I e I935 em Araras/SP. Nesse último ano ingressou no curso de Geografia e História da Faculdade de Filosofia, Ciências e Letras (FFCL) da USP por comissionamento ${ }^{2}$. Graduou-se em geografia e história pela FFCL/USP na segunda turma, em I937, ocasião em que recebeu distinção na cadeira de história da civilização. Em maio de I938, foi convidada pelo regente da cadeira de história da civilização americana, Paul Vanorden Shaw, para exercer a função de assistente adjunto de $2^{\mathrm{a}}$ categoria. No ano seguinte passou às funções de assistente adjunto de $\mathrm{I}^{\mathrm{a}}$ categoria e em $\mathrm{I} 942$ logrou a posição de $\mathrm{I}^{\mathrm{a}}$ assistente em tempo parcial, após ter defendido a tese de doutoramento intitulada O comércio português no Rio da Prata (I580-I640), orientada por Jean Gagé e aprovada pela banca examinadora com distinção (CANABRAVA, I944)33. Em I946, ao submeter-se ao concurso para a cadeira de história da civilização americana, obteve o título de livre-docente, uma vez que para os candidatos preteridos, mas que obtivessem nota superior a sete, era conferida

2 Em I935, frente ao pequeno número de matriculados no segundo ano dos cursos da FFCL, o governo estadual abriu edital para que os professores que tivessem cursado Escola Normal pudessem ingressar na FFCL por meio de uma prova e com vencimentos, contanto que mantivessem boas notas ao longo do curso.

3 Apresentada no dia I3 de novembro de I942, foi aprovada com distinção e recebeu nota 9,56 pela comissão examinadora composta dos professores: Jean Gagé, presidente da banca; Plínio Ayrosa, Pierre Monbeig, Alfredo Ellis Júnior e Eurípedes Simões de Paula (ERBERELI JÚNIOR, 20I6). 
tal titulação. $\mathrm{O}$ título foi obtido com a tese $\mathrm{A}$ indústria do açúcar nas ilhas inglesas $e$ francesas do Mar das Antilhas (I697-I755) (CANABRAVA, I98I)4.

Quando da fundação da Faculdade de Ciências Econômicas e Administrativas (FCEA) da USP em I946, foi contratada pelo prazo de um ano como técnico de administração do Instituto de Administração da FCEA do setor de pesquisa histórica. Findo o prazo, foi contratada por prova de títulos para reger a cadeira de história econômica daquela faculdade, na qual se tornou a primeira mulher catedrática da USP no concurso de provas e títulos em I95I, com a tese $O$ desenvolvimento da cultura do algodão na Província de São Paulo (I86I-I875) (CANABRAVA, 20II)5. Foi uma das fundadoras da Associação dos Professores de História do Ensino Superior (Apuh), atual Associação Nacional de História (Anpuh), na FFCL de Marília/SP em I96I; sócia efetiva do Instituto Histórico e Geográfico de São Paulo (IHGSP); desde I975, sócia correspondente do Instituto Histórico e Geográfico Brasileiro (IHGB); sócia efetiva da Academia Paulista de História, na cadeira "André João Antonil”; fundadora, em I98I, da Revista Brasileira de História. Em I986 foi eleita professora emérita da USP (ERBERELI JÚNIOR, 202I).

O IEB/USP foi concebido por Sérgio Buarque de Holanda e objetivava reunir todas as cadeiras da USP que tomassem por objeto assuntos relacionados à civilização brasileira em uma concepção de pesquisa multidisciplinar (CALDEIRA, 2002). Alice Canabrava, como regente da cadeira de história econômica geral e do Brasil da FCEA/USP, fez parte do Conselho de Administração do IEB/USP empossado em Io de outubro de I962. Ao longo de quase 20 anos Alice Canabrava atuou como chefe do setor de pesquisa e documentação e coordenou a área de história de importante evento: o Encontro Internacional de Estudos Brasileiros: I Seminário de Estudos Brasileiros realizado em I97I (ERBERELI JÚNIOR, 202I).

Além desta introdução, o artigo divide-se em mais três sessões: "De coleção a fundo: o processo de organização do Fundo Alice Piffer Canabrava”; "Os gestos arquivísticos de Alice Piffer Canabrava" e "Algumas palavras finais".

4 Para o concurso apresentaram-se mais dois candidatos: Astrogildo Rodrigues de Mello, que regia a cadeira interinamente e tinha Alice Canabrava por assistente; e Odilon de Araujo Grellet, bacharel em ciências jurídicas e sociais e professor do Ginásio Estadual Franklin Roosevelt. A banca examinadora foi formada por dois membros indicados pelo Conselho Universitário: Zeferino Vaz, da Faculdade de Medicina Veterinária, e Jorge Americano, da Faculdade de Direito. Outros três membros foram indicados pela FFCL: Eremildo Luiz Vianna e Jaime Coelho, da Faculdade Nacional de Filosofia da Universidade do Brasil, e Sérgio Buarque de Holanda, do Museu Paulista. Mesmo obtendo as maiores notas, Canabrava foi preterida por ser mulher (ERBERELI JÚNIOR, 20I6).

5 A banca examinadora foi composta de: José Joaquim Cardoso de Mello Neto, que lecionava economia política na Faculdade de Direito do Largo São Francisco, na função de presidente; Theotonio Monteiro de Barros Filho, catedrático da cadeira de ciência das finanças e diretor da FCEA; Paul Hugon, da cadeira de economia política, finanças e história das doutrinas econômicas da FFCL e da cadeira de economia política e história das doutrinas econômicas da FCEA; Afonso Taunay e Sérgio Buarque de Holanda, do Museu Paulista. Em I95I a tese foi resenhada por Sérgio Milliet e, no ano seguinte, por Fernand Braudel (ERBERELI JÚNIOR, 20I6a). 


\section{De Coleção a Fundo: o processo de organização do Fundo Alice Piffer Canabrava}

A coleção Alice Piffer Canabrava, composta de biblioteca e acervo documental, chegou ao Instituto em $2005^{6}$. Sua biblioteca não foi integralmente incorporada ao IEB/USP, uma vez que, conforme comissão de técnicos do Instituto em visita ao acervo, juntamente com seu ex-orientando Iraci Del Nero da Costa - indicado pela historiadora -, I/3 do acervo estava comprometido por cupins (ATA..., 2003).

A Coleção Alice Piffer Canabrava ${ }^{7}$ contava com aproximadamente 2 mil volumes não processados em sua biblioteca (livros, separatas, teses e revistas) e $3 \mathrm{I} 6$ documentos processados, compostos de variados tipos documentais, como programas de cursos, comunicados, recibos, resumos de eventos, artigos de periódicos e, principalmente, anotações e correspondências (IEB/USP, 20Io, p. 73) ${ }^{8}$. Com a incorporação do restante do espólio da historiadora 9 - que na verdade possui maior acervo documental que o primeiro -, a coleção passou a constituir um fundo ${ }^{\mathrm{To}}$, com, atualmente, 804 itens documentais descritos ${ }^{\mathrm{II}}$.

Após todo o tratamento técnico inicial (limpeza mecânica, desmetalização e estabilização), é necessário que se promova o arranjo do fundo. Diante da vasta gama de tipos documentais, desde fotos e cartões-postais, passando por cadernos de receita culinária, boletins escolares, documentação de Guilherme Ahlberg, seu mordomo, que adotou por irmão, documentação de sua irmã Clementina, até correspondências "profissionais" e "familiares", procedeu-se à elaboração do quadro de arranjo para a descrição documental do Fundo Alice Piffer Canabrava na base de dados do Arquivo/ IEB (Sistema de Gerenciamento de Acervos - SGA) ${ }^{\mathrm{I}}$. Esse quadro de arranjo (Figura

6 O processo de organização do Fundo Alice Piffer Canabrava do Arquivo do IEB/USP encontra-se originalmente descrito em minha tese de doutorado (ERBERELI JÚNIOR, 20I9).

7 Compreende-se por coleção "conjuntos de documentos de vários tipos e origens reunidos por uma pessoa ou instituição, em geral relacionados a um assunto ou a uma personalidade” (IEB/USP, 20Io, p. 57).

8 Essas informações também estão disponíveis no Guia do IEB (IEB/USP, 20Io).

9 Esse espólio também era integrado por I26 títulos de livros que foram transferidos para a Biblioteca do IEB/ USP.

Io "Por fundo, compreende-se um conjunto de documentos de caráter pessoal, científico, artístico, profissional ou técnico produzidos e/ou reunidos em decorrência das atividades de seu titular" (IEB/USP, 20Io, p. 57).

II Heloísa L. Bellotto (2007, p. I28), uma das maiores estudiosas de arquivística do país e que trabalhou como pesquisadora do IEB, fornece-nos uma ampla definição de fundo e uma advertência: "Admite-se como fundo o conjunto de documentos produzidos e/ou acumulados por determinada entidade pública ou privada, pessoa ou família, no exercício de suas funções e atividades, guardando entre si relações orgânicas, e que são preservados como prova ou testemunho legal e/ou cultural, não devendo ser mesclados a documentos de outro conjunto, gerado por outra instituição, mesmo que este, por quaisquer razões, lhe seja afim". O princípio da proveniência é a base da teoria dos fundos, uma vez que estes devem ser organizados de acordo com a origem do documento e seu órgão produtor.

I2 A elaboração do quadro de arranjo é pautada no princípio da proveniência. Para a sistemática de elaboração do arranjo, ver: Bellotto (2007a, p. I35-I45). 
I) foi concebido a partir da abordagem contextual da teoria arquivística, ou seja, cada grupo e subgrupo do quadro insere os tipos documentais em seus contextos de produção, em que se pergunta "como" e "quando" foram produzidos ${ }^{\mathrm{I3}}$ (CAMARGO; GOULART, 2007):

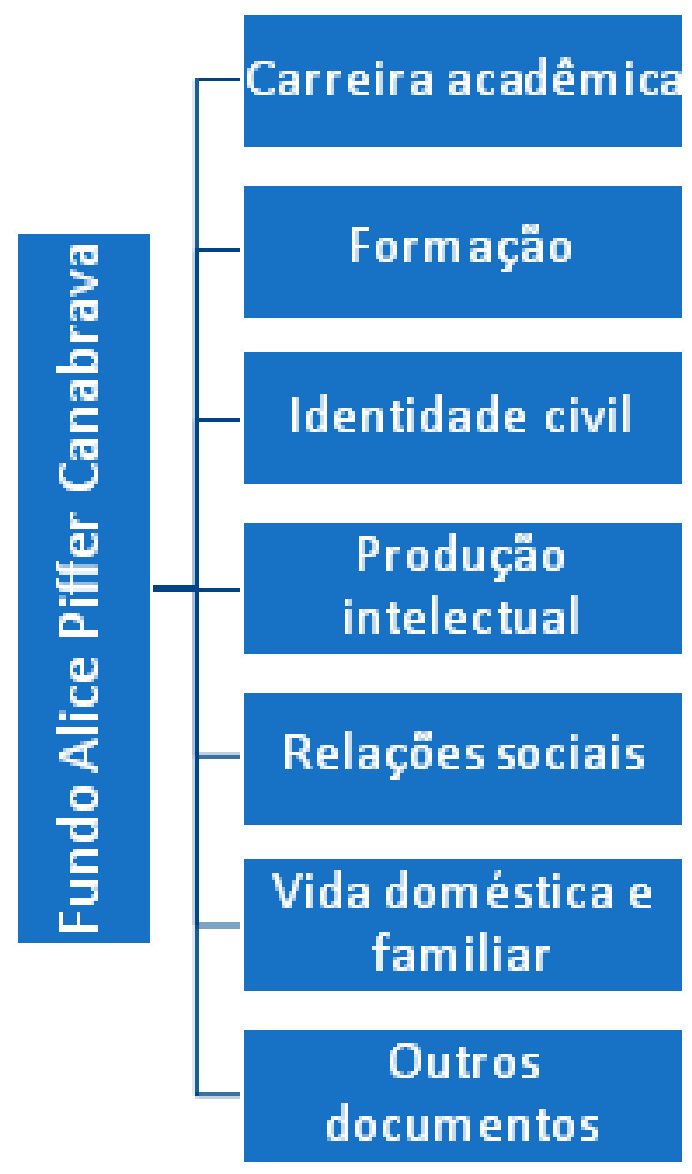

Figura I - Quadro de arranjo define a descrição documental do Fundo Alice Piffer Canabrava

Em "Carreira acadêmica" se encontra documentação relacionada às atividades profissionais de Alice em várias instituições, como a Associação de Geógrafos Brasileiros (I item) e a Fundação Instituto de Pesquisas Econômicas (3). No grupo "Formação" está a documentação produzida por sua vida escolar, como o subgrupo “Ginásio", em que estão seus boletins escolares do Colégio Stafford (2).

I3 Agradeço a Elisabete Marin Ribas pela colaboração na elaboração do quadro de arranjo. 


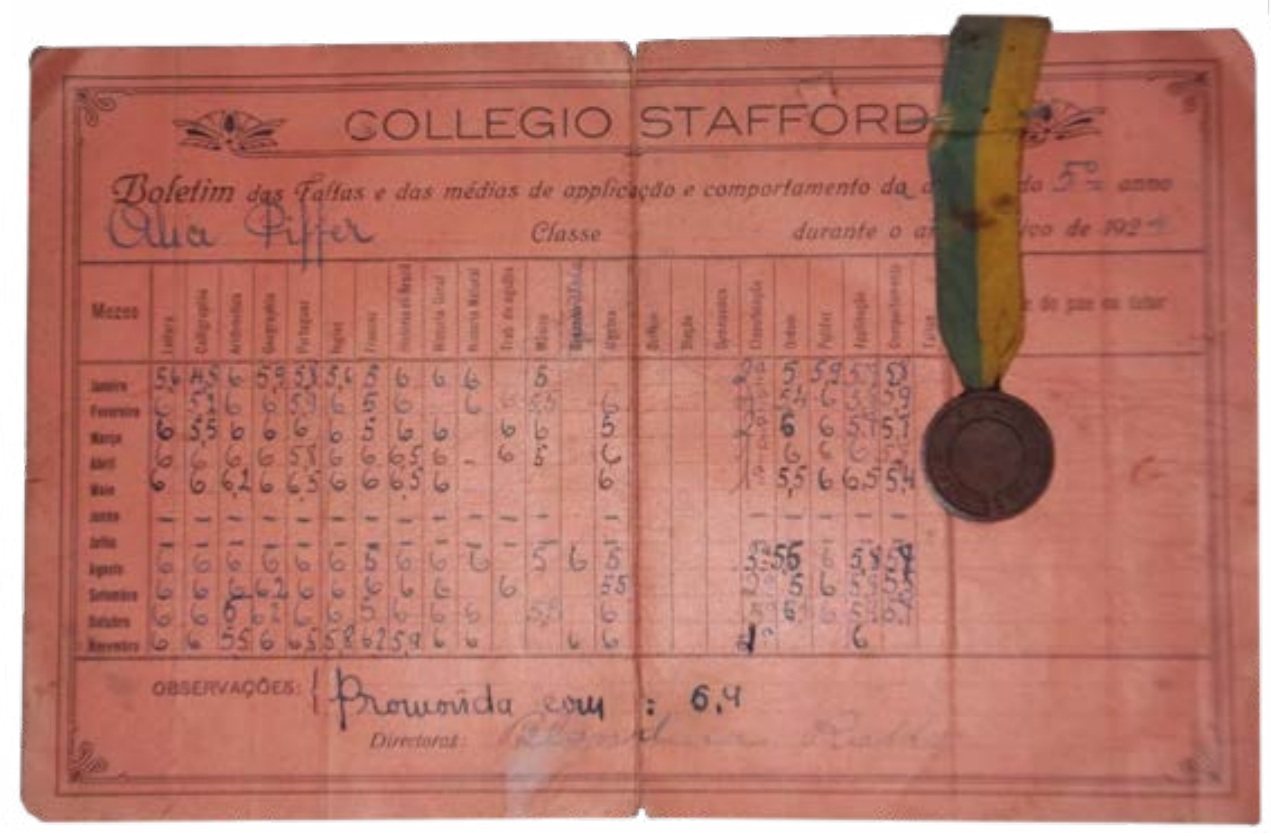

Figura 2 - Boletim do Colégio Stafford, I924. Fundo Alice Piffer Canabrava, Arquivo IEB/USP, código de referência APC-GIN-ooI

Em seguida, no grupo “Identidade civil”, estão os documentos que fornecem a inserção da titular do fundo enquanto cidadã brasileira, como certidão de nascimento, cédula de identidade, passaportes etc. (8).

O grupo seguinte, que reúne os documentos produzidos pela historiadora na elaboração de suas obras, denominado "Produção intelectual”, está dividido em três subgrupos de acordo com o que conseguimos identificar como documento produzido em preparação para determinada obra, como o subgrupo "O desenvolvimento da cultura do algodão na Província de São Paulo (I86I-I875)" (5), tese produzida pela titular do fundo para a obtenção da cátedra de história econômica da FCEA/USP. Há ainda os subgrupos "Estudos para a obra de Alice P. Canabrava” (45), em que se incluem diversas anotações de pesquisa e levantamentos bibliográficos, e "O comércio português no Rio da Prata (I580-I640)” (I), que agrupa anotações para a elaboração de sua tese de doutoramento apresentada em I942 na FFCL/USP.

No grupo "Relações sociais", encontra-se alocada documentação produzida por Alice Canabrava em função do que François Sirinelli (2003) formulou como redes de sociabilidade. São correspondências geradas a partir de sua atuação como professora primária em Araras/SP e de sua carreira acadêmica, com outros acadêmicos do período, orientandos e amigos (587). Os mais frequentes correspondentes da historiadora foram: Francisco Iglésias (63 itens), professor da antiga Faculdade de Ciências Econômicas da Universidade de Minas Gerais (SANTOS, 20I7); Maria Celestina Teixeira Mendes Torres (I8), sua colega 
de turma na graduação em geografia e história na FFCL/USP em I937 e sua primeira assistente de pesquisa na FCEA/USP; Antônio Emílio Muniz Barreto (I6), seu orientando de doutoramento; Zélia Maria Cardoso de Mello (I2), sua orientanda de doutoramento ${ }^{\mathrm{I}}$.

I4 Outros correspondentes menos assíduos: Arquivo Público e Histórico do Município de Rio Claro/SP, Mbá de Ferrante, Adalberto Marson, Akihiro Ikeda, Alcides Serzedello, Aníbal Abadil-Aicardi, Antônio Atrazas, Antônio Carlos da Ressurreição Xavier, Beatriz Ricardina de Magalhães, Benedicto Heloiz Nascimento, Boris N. Komissarov, Branca Caldeira, Carlos Viacava, Célia Freire D’Aquino Fonseca, Célio da Cunha, Centro Acadêmico "Visconde de Cairu”, Charles M. Hardin, Charles Boxer, Cid José Teixeira Cavalcante, Consuelo Meyer, Daniel Valle Ribeiro, Daphne Cesar, Eduardo Pereira de Carvalho, Estella Ferraz Costa Negraes, Eva Alterman Blay, Fernand Braudel, Fernando Manuel de Mendonça, Francisco de Assis Barbosa, Francisco Vidal Luna, Frederic Mauro, Edmundo de Macedo Soares e Silva, George Jekabson, Geraldo Cardoso, Gil José Pace, Hans Schellenberg, Harry Bernstein, Helga I. L. Piccolo, Hélio Dantas, Heloísa Liberalli Bellotto, Ibrahim João Elias, Joaryvar Macedo, Jornal da Roselância, José Aderaldo Castello, José Albertino Rosário Rodrigues, José Bonametti, José Brendan Macdonald, José Ênio Casalecchi, José Francisco de Camargo, José Gonçalves Salvador, José Luiz Pasin, José Ribeiro Júnior, José Roberto Barreto, José Roberto do Amaral Lapa, José Sebastião Witter, Kátia M. de Queirós Mattoso, Laura de J. Nunes, Lewis U. Hanke, Lúcia, professora do Grupo Escolar de Araras/SP, Manoel Salvador Ramos, Manuel Correia de Andrade, Maria Amélia Buarque de Holanda, Maria Luiza Alvarenga Freire Carette, Maria Yeda Leite Linhares, Mário Portugal Fernandes Pinheiro, Mário Wagner Vieira da Cunha, Mircea Buescu, Mirian L. Moreira Leite, Norma de Góes Monteiro, Oswaldo da Silveira Neves, Paulette Braudel, Paulo Mendroni, Pedro Calmon, Pedro Martinello, Peter Louis Eisenberg, Raquel Glezer, Richard Graham, Romulo Garcia de Andrade, Ronaldo Marcos dos Santos, Ruy Ribeiro de Moraes Leme, Sociedade Geográfica da URSS, Tamás Szmrecsanyi, Theo Santiago, Vilma dos Santos Cardoso Monteiro, Willian Alan Cole, Wilson Cano, Liceu de Humanidades de Campos e Museu da Imagem e do Som/SP. 
Querida, prof. Alce.

Recebi todas al suas cartaa que taito ke alegraran, receb1 as fotocra-

fyas, o zeu diseurso, quo, aches nujto bonito. Reazeente ze egocionou. Ja libe disae, e repito, só sinto nio ter estado al por ocasiäo destes eventog. Cosq, a sonhora sabe, sua influenela na, binha vida, na, sinha trajetoria fundasentai e gostaria de estar of para hosenages-1a. Kas, por outro lado, a sua aposentadoria fio, significa a sua ausencia, fefizsente, neste sentido, a data näo ó rundusenta.

coso jo the eacrev1, egsecel finaleente a aproveltar Londros. Passel orktal aqui cos zegl irkao, que velo dos Bstados unidos. Depols fo-

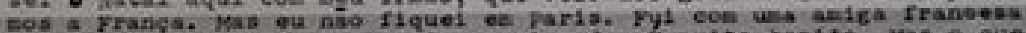
pora os al pes. Fiquel euito iepressionada. E Eut to bonito, yas o que pe impressionou rot a capacidade de adaptacio do ser nueano. Figer naquele frio, sespre cos as ruas o casas cobertas de neve... : E preclso us roups especial, alikentagajo especial, enfir, una sorie de providenolus para garantir a vida. Flcasos na casa de uns primos desta inha asiga. Tve portanto, oporturibade de conbecor nao coto turiata. ilgda que por poucos disa jude perceber sogs hábites, suas proocupacoes, experizentar a cozida ţlpica da regilo (que é ótita) $\$$ ouvir frances o tespo todo. Dles so falavas es rrances e fol diflolix a cosunieagáo, fas del "para gliebrar o ealhon. Depols voltei a paris no rla de secana. Realmente eu gdoro paris. Nab ne reflro necessariasente aos francesed, pas s oldade é nal to vigrante, alegre, tes ylda. As pessoas saes as ruas, i anisado. Londrgs e puito diferentgi nio se ve cente a rua, estao todos es casa, eusto discreta, eobria, protestan-

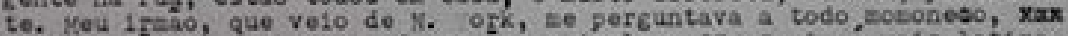
Fonde estio as pessoas, onde estio os ingloses?". Parla e majs latina, sals parecida cós jäo paudo. ¿̀ coro ea jeagine que seja a Itália, a Eapanha, glecria, viozaçao, vida social intensa. Eo Londres a vjala

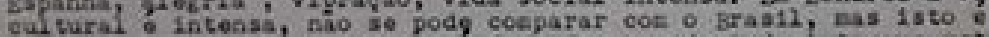
"dentre", a senhora entende?, E rechado. Mas de tydo isto que estou verdo tenho trado 11 goes e ensinasenntos. Coto Ja lhe fales tes aldo

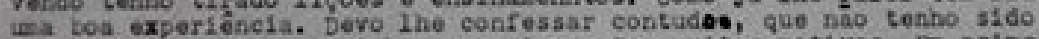
suito disciplinada es siphas pesquisas. For Eultos zotivos. Ea priselro Iugar, o tezpo, necessár1o para se adagtar e poder "olroular", ze Impediu de realiza-1as. Depols, quando ja estava instalada a ansia de conhecer tudo que a eldade pode orerecer, conhede os lugares, os ausios, as csierias, as 20 jas, enfis, tudo se desviava da jesquisa. icho que tasbie infiúlu meu cansaco, deposs da tese, pols coso a senhora sabe ra_o witimo sno fol exaystivo. Cheguel a trabalihan 18 , 19 hors

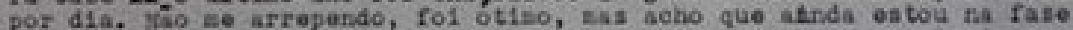
de tosar rolego para cosegar de novo. Vanos ver agora, de neste tgapo que a resta agui aprovel to algura colas neste caspo, 0 probleas e que o teepo corre e as vezes a cente nio consogue controlar.

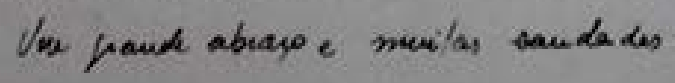

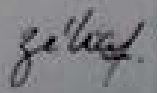

Figura 3 - Carta recebida de Zélia Maria Cardoso de Mello. Fundo Alice Piffer Canabrava, Arquivo IEB/USP, código de referência APC-MELL-003 


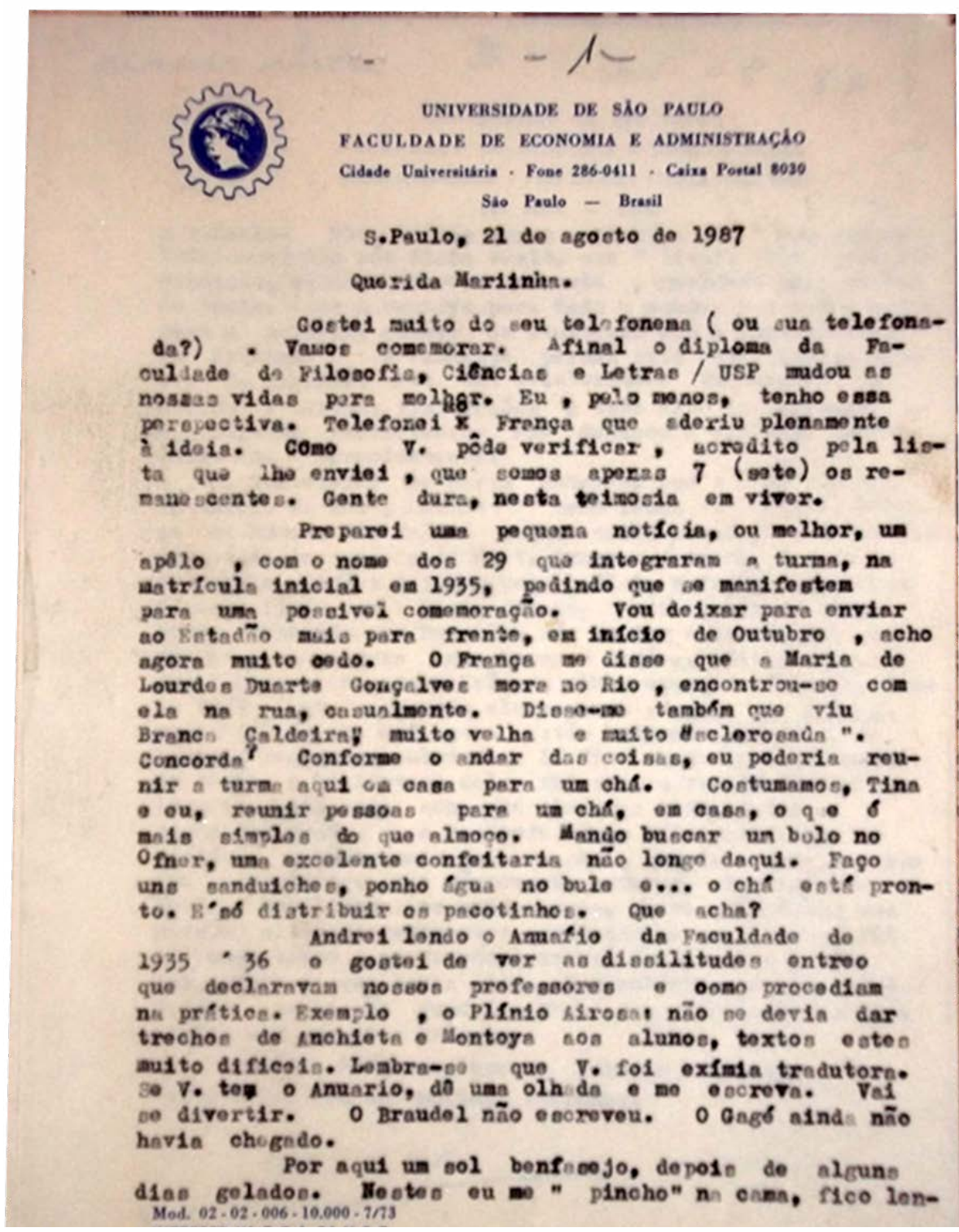

Figura 4-Cópia feita com papel-carbono de carta para Maria Celestina Teixeira Mendes Torres. Fundo Alice Piffer Canabrava, Arquivo IEB/USP, código de referência APC-TORR-oo8

Em "Vida doméstica e familiar" alocamos a documentação produzida por suas relações familiares e também em relação à organização da vida cotidiana (I3I itens). O subgrupo "Finanças" inclui documentação relacionada à vida financeira da titular, como recibos diversos, escrituras de imóveis, talões de cheques, cartões bancários etc. (38). Outro subgrupo, "Guilherme Ahlberg” (5I), inclui a documentação de Guilherme, mordomo das irmãs Alice e Clementina e que se tornou um irmão para ambas, como se referem a ele em várias cartas. Inclui receitas médicas, cédula de identidade, 
talões de cheque, cadernetas de poupança etc. O agrupamento "Vida doméstica e familiar" ainda inclui o subgrupo "Saúde", onde constam receitas médicas e cartão de vacinação da titular. Por último, em "Outros documentos" estão tipos documentais variados, como aulas, cartas etc.

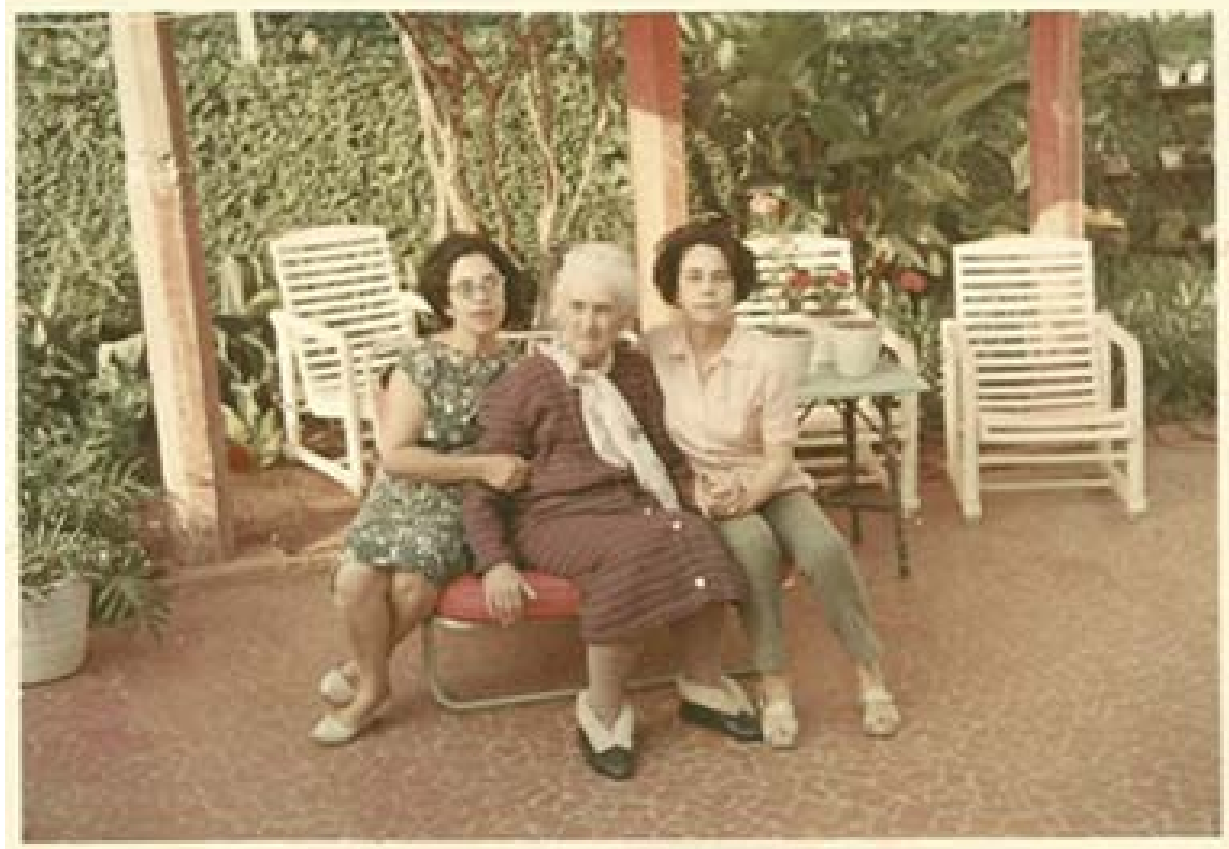

Figura 5 - Da esquerda para a direita: Alice Piffer Canabrava; sua mãe, Ottília Piffer Leonardi; sua irmã, Clementina Canabrava. Sem data/ sem local. Fundo Alice Piffer Canabrava, Arquivo IEB/USP ${ }^{\mathrm{I5}}$

I5 Algumas imagens estão sem a referência completa porque ainda não foram descritas e inseridas no Catálogo Eletrônico do IEB. A escolha dos documentos se deu a partir do acervo de imagens do autor, uma vez que o Arquivo IEB/USP se encontra fechado para consulta. 


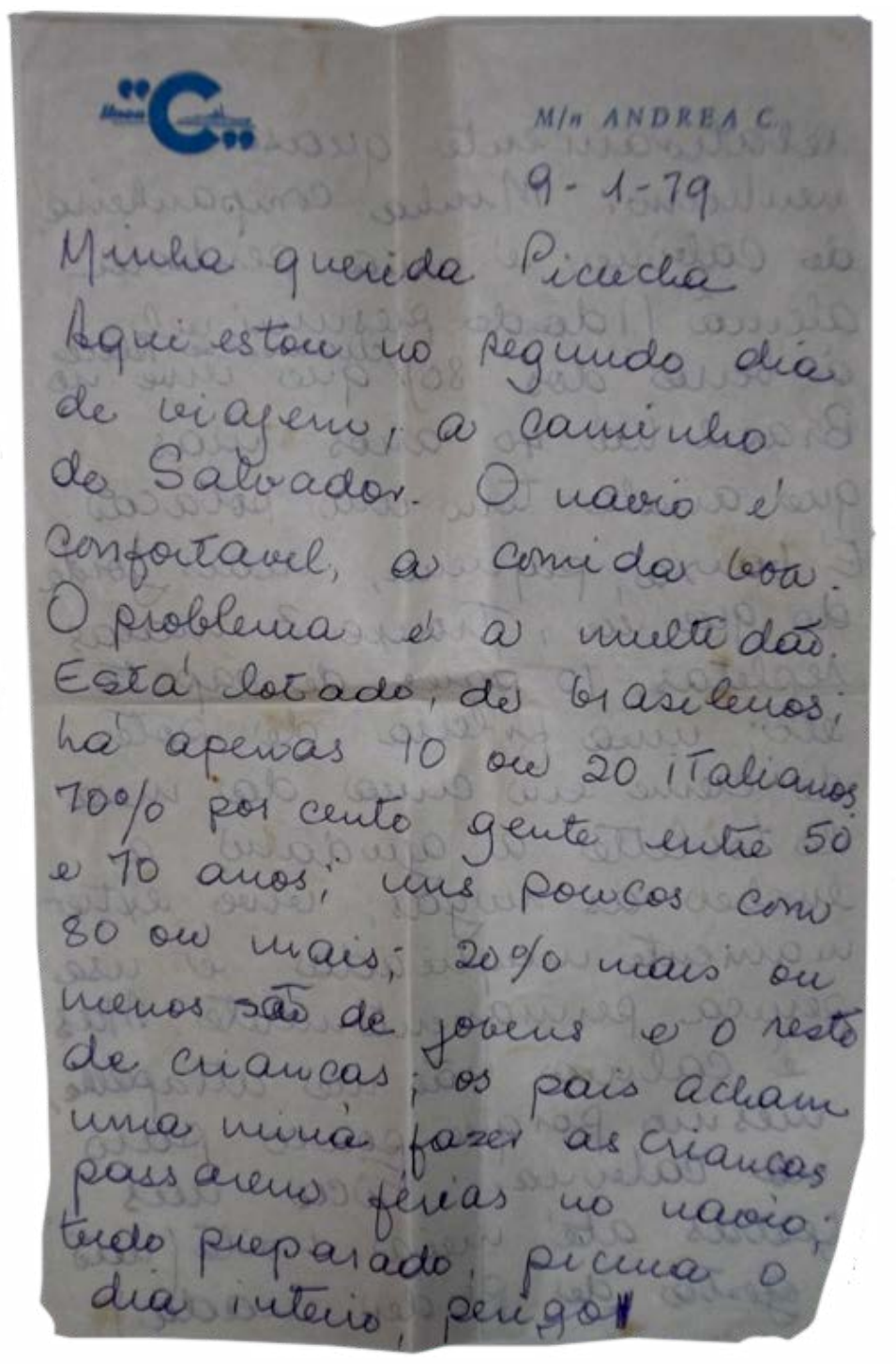

Figura 6 - Carta recebida de sua irmã Clementina Canabrava (Tina). Fundo Alice Piffer Canabrava, Arquivo IEB/USP, código de referência APC-CANA-007

Após a formulação do quadro de arranjo, passa-se ao processo de descrição documental, cujo objetivo é a elaboração de instrumentos de pesquisa. O trabalho de descrição realizado pelo arquivista deve identificar, condensar e apresentar todas as possibilidades de uso e aplicação da documentação descrita, com o fito de proporcionar um profícuo encontro entre o historiador e a documentação. Por isso, a intensa sinergia entre arquivística e história, uma vez que o arquivista deve estar ciente das práticas de pesquisa historiográfica para uma descrição que sirva ao historiador (BELLOTTO, 2007b, p. I73-I78).

206 [

revista do Instituto de Estudos Brasileiros $\cdot$ n. $80 \cdot$ dez. 202I (p. I96-2I8) 
No caso do Arquivo/IEB, essa descrição é inserida em seu SGA, interligado ao Catálogo Eletrônico que dá acesso a uma busca integrada entre Arquivo, Biblioteca e Coleção de Artes Visuais. Um catálogo é elaborado no nível das séries que formam um fundo, e sua base de descrição são as unidades documentais (LOPES, 2002) ${ }^{16}$. No Arquivo do IEB adota-se um nível de descrição por unidade documental.

\section{Os gestos arquivísticos de Alice Piffer Canabrava}

Michel de Certeau concebe a história enquanto heterologia, ou seja, enquanto um discurso sobre o outro ${ }^{\mathrm{I7}}$. Nesse caso, para o historiador, o passado. Através dos restos, ou rastros, vestígios desse outro, o historiador procede, através de seu texto, ao encurtamento dessa alteridade, porém sem conseguir apagar suas marcas. Forja a presença de um ausente. Sendo a ausência condição de possibilidade do discurso histórico ${ }^{\mathrm{T}}$.

I6 Há ainda outros instrumentos de pesquisa, como o guia, primeiro instrumento de um arquivo, o inventário e o índice. $\mathrm{O}$ guia possui como base de descrição conjuntos documentais amplos e deve fornecer uma radiografia geral do arquivo, como suas origens, seus fundos e coleções, endereço, formas de contato, formas de consulta e requisitos para tanto. Na sequência de descrição hierárquica, temos o inventário, que deve fornecer uma descrição dos fundos do arquivo ou suas coleções. Há também os índices, que procuram decompor os documentos em descritores, que podem ser temáticos, cronológicos, geográficos, onomásticos etc. Faz-se mister a utilização de um vocabulário controlado em sua elaboração. O mais comum é que o índice seja adotado dentro de outros instrumentos de pesquisa.

I7 Ver, principalmente: Certeau (20I0). Trata-se de trabalhos dispersos de Certeau que foram traduzidos por Brian Massumi e revisados por Luce Giard sob a supervisão do jesuíta-historiador. A maioria dos textos presentes nesse livro compõe a edição: Certeau (20I2). O livro original data de I986, e sua edição ampliada, de 2002. Conta com prefácio de Luce Giard intitulado “Um caminho não traçado”.

I8 Em texto publicado em I970, proveniente de conferência no Centre de intellectuels catholiques em I969, intitulado "História e estrutura", Michel de Certeau utiliza-se da metáfora do morador de rua (clochard) para explicar práticas etnológicas e historiadoras a partir de sua experiência com a história religiosa do século XVI. Ao iniciar seus estudos sobre a Companhia do Santo Sacramento, Certeau confessa que sua prática estava impregnada por uma busca identitária: imaginava que encontraria razões para sua fé cristã nesse passado. Qual seu embasbacamento ao se deparar com a diferença. O morador de rua, para Certeau, assemelha-se ao etnólogo na medida em que, ao exumar nas latas de lixo restos de mantimentos ou roupas, sonha com a casa em que nunca irá morar, com a refeição que nunca terá e com intimidades de que nunca desfrutará. A partir dos restos catados, inventa mundos que nunca irá frequentar. Da mesma maneira procede o historiador quando frequenta arquivos e bibliotecas. Esses "restos" catados pelo historiador permitem somente que encontre esse outro em sua imaginação. Essa ausência é uma condição para o discurso histórico (CERTEAU, 20I2a, p. I63-I78). Não por acaso, o capítulo seguinte do livro História e psicanálise intitula-se "O ausente da história" e foi publicado originalmente em I973. Nesse texto, Certeau nos convida a pensar a história enquanto uma heterologia, ou seja, como um discurso sobre o outro. Esse outro pode ser tomado como tudo aquilo que instaura uma diferença: o europeu em relação ao novo mundo; o Outro, como Deus para o místico; a linguagem do possuído; a mulher para o homem etc. 
Muito afeito a metáforas ${ }^{\mathrm{Ig}}$, Certeau evoca o personagem Robinson Crusoé, também título do romance de Daniel Defoe publicado em I7I9, para refletir acerca dos procedimentos do historiador em relação aos vestígios do passado. Crusoé é o único sobrevivente de um naufrágio e está em uma ilha deserta. Organiza toda uma técnica para que possa sobreviver através da construção de uma cabana e coleta de alimentos. Porém, algo perturba sua economia. Crusoé delira em sonhos após ver pegadas na areia. Não estaria sozinho? Quem é esse outro? Crusoé está em devaneios. Aqui, Certeau entrevê os lugares que no século XIX serão ocupados, respectivamente, pela ciência econômica e pela interpretação dos sonhos; pela racionalidade e pela ficção. O outro de Crusoé se desvela: é Sexta-feira, um nativo que irá escravizar. Ao contrário desse outro de Crusoé, o outro do historiador é ausência permanente; não chega, não volta. Deixa somente pegadas, vestígios... (CERTEAU, 20I2b, p. I79-I88).

Entre 20I5 e 20I6, ao adentrar, quase todos os dias, a sala número 2 do Arquivo/ IEB, com umidade e temperatura controladas, bastante fria, me sentia procedendo tal qual médico legista ao tomar um corpo e, a partir de evidências fisiológicas, tentar inferir uma causa mortis. Com luvas de látex, colocava os "restos mortais" na forma de "rastros mortais" de Alice Canabrava no carrinho do arquivo e rumava para a sala de trabalho a fim de exumá-los; no caso, descrevê-los.

Cartas recebidas de sua irmã, Clementina; cartas recebidas de sua mãe, Ottília; cartas recebidas de amigos e de colegas historiadores; cartas recebidas de seus orientandos. Cartões-postais remetidos de diversas partes do mundo, por amigos, colegas e por sua irmã. Fotos quando professora em Araras/SP; fotos ainda moça em excursões com sua turma do curso de geografia e história da FFCL/USP promovidas pelo geógrafo Pierre Monbeig, regente da cadeira de geografia física e humana; fotos de formatura; fotos em sua casa, em jantares com os assistentes de pesquisa e auxiliares de ensino da cadeira de história econômica da FCEA/USP ${ }^{20}$; fotos com sua mãe, sua irmã e seu irmão por adoção. Canabrava nunca está sozinha, sempre em

I9 As noções de estratégia e tática são provenientes de uma metáfora de guerra. Esse par talvez seja o mais usado entre historiadores, antropólogos e cientistas políticos, conforme pude inferir das apresentações do Colóquio Michel de Certeau em Uso, organizado pelo coletivo Artes, Saberes e Antropologia (ASA) do departamento de Antropologia da FFLCH/USP entre I9 e 2I setembro de 20I6 (COLÓQUIO Michel..., 20I6). Grosso modo, a estratégia vincula-se ao planejamento de longo prazo e relaciona-se ao poder dos fortes, enquanto a tática é forjada pelos mais fracos com o fito de subverter a estratégia dos dominantes e, por isso, vincula-se ao tempo curto, ao instante. A tensão imbricada na relação entre estratégia e tática não se resolve dialeticamente, pois uma não existe sem a outra (CERTEAU, 20I4, p. 86-IOO). Essa edição é estabelecida e apresentada por Luce Giard. Na conferência de abertura desse Colóquio, Luce Giard atribui a inspiração da elaboração desse par nocional à leitura da obra de Marx pelo grupo de jesuítas da casa na qual Certeau morava e de que foi participante.

20 Como, na ocasião de sua aposentadoria, conforme relatado em carta a Francisco Iglésias em I7 de novembro de I98I: "Minha aposentadoria saiu afinal dia 2I de outubro e desde então, só agora, nesta semana, tenho um pouco de folga. Andei muito ocupada. Resolvi reunir os colegas do IPE e da Faculdade, aqui em casa, para um almoço, um almocinho simples. Trinta pessoas. Devo muito aos meus amigos do IPE, quase todos meus ex-alunos” (CANABRAVA, I98Id). 
alteridade. É muitas: irmã, filha, professora, orientadora, colega, amiga, historiadora... Muitas são as pegadas. Muitas são as Alices.

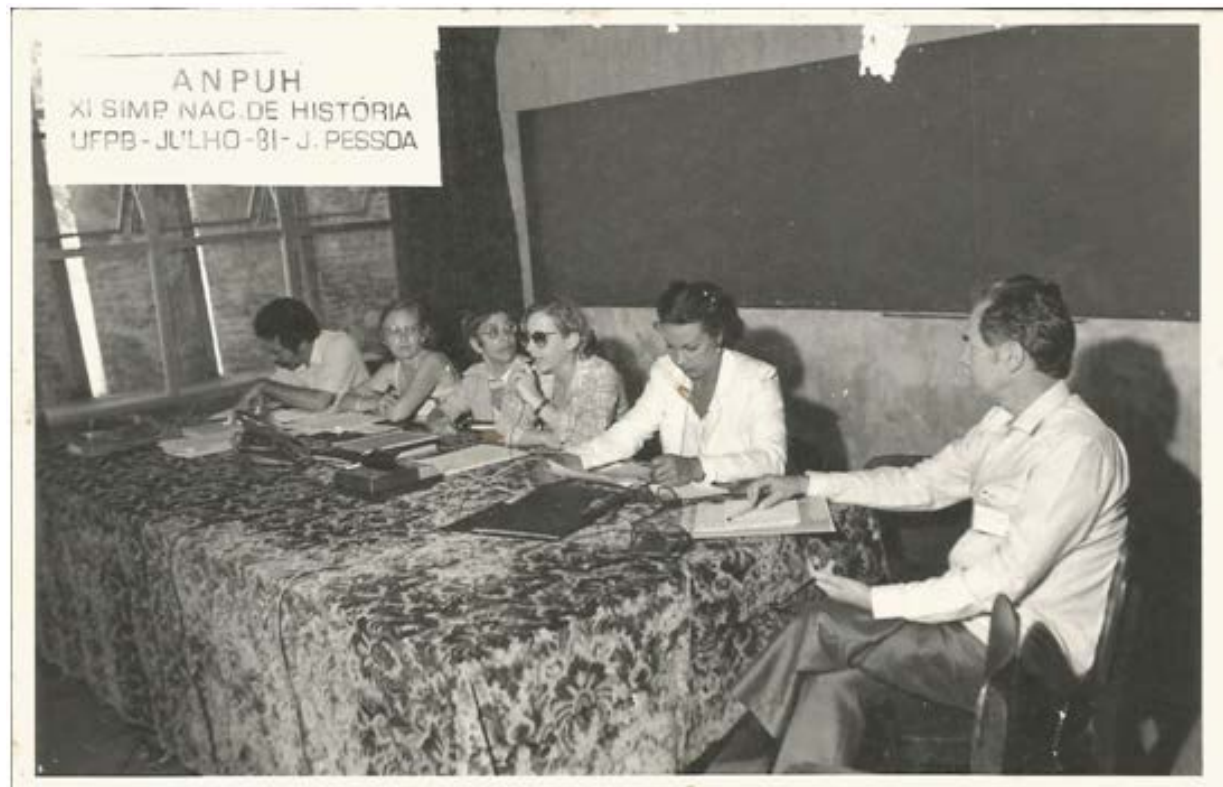

Figura 7 - Alice Canabrava, na ocasião presidenta da Anpuh, em mesa do XI Simpósio Nacional de História, realizado em I98I em João Pessoa/PB (terceira, da esquerda para a direita). Fundo Alice Piffer Canabrava, Arquivo IEB/USP

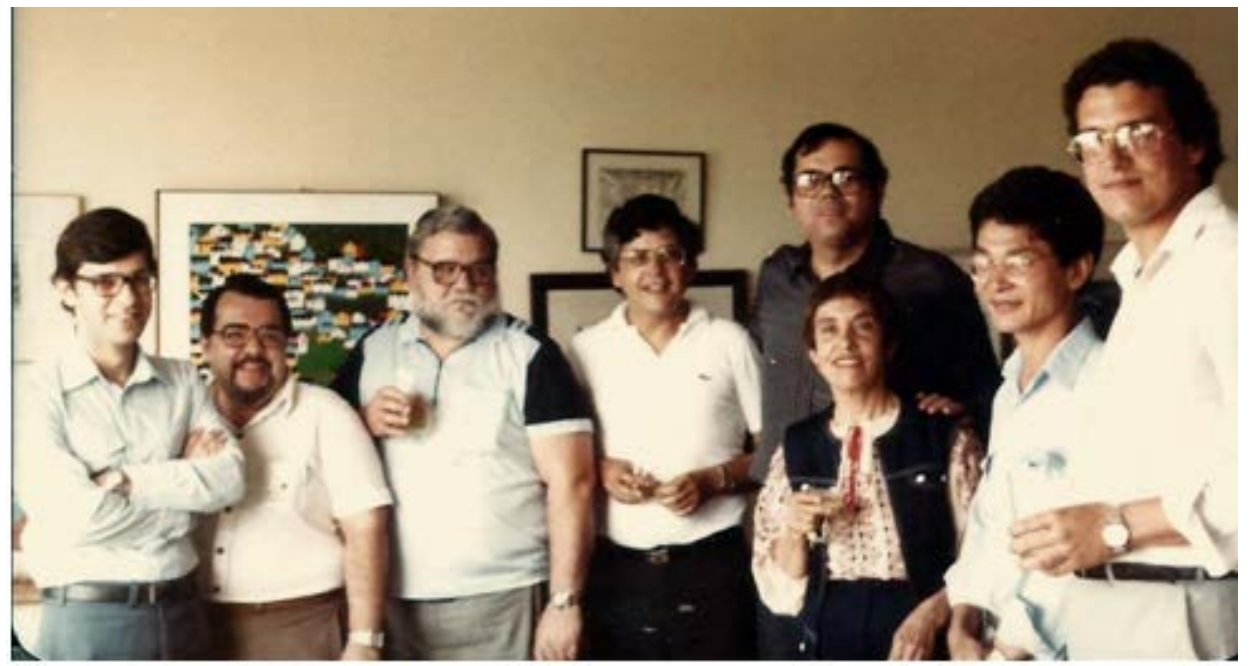

Figura 8 - Reunião na casa de Alice, na rua Macapá, na cidade de São Paulo/SP, com os que foram, em diversos momentos, seus auxiliares de ensino, assistentes de pesquisa e orientandos. Sem data. Fundo Alice Piffer Canabrava, Arquivo IEB/USP 
Três questões despertaram minha atenção no convívio com esse outro ausente: por que o espólio foi doado ao IEB/USP? Por que uma parte foi doada em 2005 e a parte mais significativa, dez anos depois, em 20I5? O que aconteceu com o restante de seu espólio, uma vez que alguém que por toda vida nunca fez uso de computador teria um volume de documentação muito maior do que o que compõe seu Fundo? Teria Canabrava se desfeito de uma parte de seus papéis? Por fim, por que ela possuía cópias feitas com papel-carbono de várias cartas remetidas, estaria "arquivando a própria vida" ${ }^{2}$ ?

Em 24 de junho de 1975 a historiadora deixou carta à sua irmã Clementina (referida por "Tinin") para que, em caso de morte repentina, modificasse seu testamento. Um dos pontos a serem alterados dizia respeito à doação de seus livros, que deveriam ser vasculhados com o fito de averiguar se dentro de algum constariam papéis particulares; proceder à seleção dos mesmos e doá-los ao IEB/ USP e não mais à FEA/USP, asseverando que a esta última nada deveria ser doado (ATA..., 2003). Na mesma carta, Alice Canabrava determina que todos os seus papéis "escritos à mão e à máquina, (materiais de estudo, fichas de estudo, cópia de fontes etc.) tudo deverá ser queimado"22. Apenas sua coleção de cartões de natal deverá ser

2I Não somos os primeiros a empreender estas reflexões. A partir de sua experiência de pesquisa em arquivos pessoais de várias instituições francesas, Rafael F. Benthien aponta algumas questões relevantes ao pesquisador que se envereda por esse tipo de arquivo. Sua ida aos arquivos pessoais de Henri Hubert, Salomon Reinach e Joshep Déselette relaciona-se com sua pesquisa de doutoramento envolvendo o problema da institucionalização da sociologia na França ante o já consolidado campo de estudos clássicos, compreendido pelos helenistas e latinistas (BENTHIEN, 20II). A partir de figuras-chave para a institucionalização da sociologia na França, como Durkheim e Marcel Mauss, Benthien se depara com toda uma rede de relações que envolvia o estudioso das religiões, o sociólogo durkheimiano Hubert, e os arqueólogos Reinach e Déselette, uns dos poucos que dialogavam com a sociologia e a antropologia. O "impessoal" dos arquivos pessoais diz respeito à importância de ter em conta três procedimentos metodológicos: historicizar o arquivo, ou seja, a história de sua composição, como foi acumulado pelo indivíduo, porque foi doado a esta ou àquela instituição, desde quando está acessível ao pesquisador; conhecer as instituições e os sistemas aos quais estão vinculados; relacionar um arquivo pessoal a outros, uma vez que é muito difícil que se tenha a totalidade da correspondência ativa e passiva do titular do acervo ou fundo. Dessa maneira, é possível vislumbrar as lacunas, silêncios etc. (BENTHIEN, 20I4).

22 Essa determinação de Alice, para que tudo fosse queimado, me lembra do personagem Matthew Pearce do romance Ever after, do escritor inglês Graham Swift - que compreende o homem como um animal narrativo em sua característica ontológica de viver entre o passado e o futuro -, na assertiva: "Keep them, burn them - they are evidence of me”. Sue McKemmish se inspira nesse personagem para empreender reflexão acerca das motivações que nos impelem a arquivar a própria vida como testemunho e os mecanismos pelos quais uma prova de si se torna uma prova de nós (MCKEMMISH, I996, p. 28-45). A compreensão de McKemmish da expressão "provas de mim" é "como sinônima de arquivo pessoal, no sentido mais amplo, reunindo todas as formas que as narrativas podem assumir" (MCKEMMISH, 20I3, p. 23). Esse texto é fruto da apresentação de conferência em evento promovido pela Fundação Casa de Rui Barbosa entre 23 e 25 de agosto de 20Io no Rio de Janeiro sobre arquivos pessoais. Nele, Sue McKemmish atualiza as reflexões empreendidas em I996 sobre as provas de si e as provas de nós em um ambiente de crescente informatização e digitalização da vida. Nele também é apresentada uma contribuição original à teoria arquivística: o records continuum. 
guardada e, posteriormente, doada a Hebe Marsiglio Carvalho (ATA..., 2003). Essa carta revogava o testamento anterior de Io de dezembro de I973, que determinava que: "no caso de sua irmã e única herdeira, Clementina Canabrava, falecer antes dela testadora, ou simultaneamente consigo, todos os bens serão assim distribuídos: -I-Os bens imóveis, os títulos de financiamento e os depósitos bancários caberão à Fipe” (CANABRAVA, I973, p. 2). Nesse caso especial, todos os seus bens seriam transferidos à Fipe/USP, onde deveriam ser utilizados para financiar pesquisas em nível de pós-graduação em história econômica do Brasil na forma de concessão de bolsas de estudos e auxílio para publicação, na condição de que fossem pesquisas originais e que se remontassem no mínimo a 40 anos no tempo.

As memórias de Alice Canabrava em relação à FFCL/USP parecem se caracterizar por uma perenidade, no sentido de, após ter sido preterida em concurso para a cadeira de História da Civilização Americana em I946, expressar os sentimentos mais negativos em relação a esse lugar social (CERTEAU, 20II, p. 45-III), seja na correspondência com seu próximo (RICOEUR, 2007, p. I4I), no caso Francisco Iglésias ("ninho de víboras") (CANABRAVA, I982), seja em entrevista ("intelectualoides extremamente preconceituosos para com a mulher”) (CANABRAVA, I997). Em relação à FCEA/USP, suas memórias expressam sentimentos em trânsito e, por vezes, contraditórios, tanto em cartas, quando concorda com seu amigo Francisco Iglésias em que seu "único bilhete de loteria" foi ter ido para a FCEA/USP em I946 (CANABRAVA, I972), quanto em entrevistas (CANABRAVA, I98Ia). Na entrevista ao Museu da Imagem e do Som de São Paulo em I98I, após ser questionada por Flávio Saes acerca das dificuldades enfrentadas pela mulher na universidade, afirma que nunca teve problemas na FCEA/ USP pelo fato de ser mulher. Porém, afirma ter sofrido muito quando foi diretora da instituição entre I954-I957, enfrentando oposição de um grupo de professores que não a queriam no cargo (CANABRAVA, I98Ia). Já em entrevista a Flávio Saes, em I997, afirma que é muita grata à Faculdade de Economia (CANABRAVA, I997).

Além dos sentimentos conflitantes em relação à FCEA/USP, uma das hipóteses para que ela tenha revogado o testamento de I973 em favor do IEB/USP diz respeito à sua relação de admiração e respeito por Sérgio Buarque de Holanda.

Quanto aos dois momentos da doação, um primeiro em 2005 e outro em 20I5, podemos apenas conjecturar. Na primeira doação realizada por Hebe Marsiglio Carvalho, foram doados livros, fichas de estudo, anotações e quatro conjuntos de correspondências passivas: de Antônio Emílio Muniz Barreto (nesse caso também há presença de cópias feitas com papel-carbono de cartas remetidas), Francisco Iglésias (o mesmo do caso anterior), Fernand Braudel e Paullete Braudel. Sua sobrinha não queimou seus papéis, ao contrário do que determinava a carta de Canabrava mencionada anteriormente. Teria Hebe M. Carvalho doado somente a parte do espólio da historiadora que pôde examinar com cuidado, procedendo a uma seleção de arquivamento de sua tia? Fato é que o restante do espólio, selecionado ou não, somente foi doado após a morte de Hebe, por sua filha e sobrinha-neta de Alice Canabrava, Lúcia Marsiglio Carvalho ${ }^{23}$.

23 Deixo aqui meu agradecimento público a Lúcia por, desde os primeiros contatos, ter se mostrado receptiva às demandas deste pesquisador, por ter-me aberto as portas de sua casa e ter a mim confiado a intermediação da doação da documentação remanescente de sua tia. 
O volume da documentação presente no Arquivo do IEB, quando confrontado com o fato de que Alice Canabrava nunca fez uso de computador, conduz-nos a inferir que ela mesma procedesse à seleção de seus papéis, arquivando uns e dispensando outros, procedimento cotidiano da maioria das pessoas com seus itens pessoais, recibos de contas pagas, cartas, material escolar de infância/adolescência, xerox etc. ${ }^{24}$. Mas, quando se trata de um historiador realizando esse procedimento, cabem algumas reflexões ${ }^{25}$.

No caso de Alice Canabrava, a guarda de seus papéis parece estar ligada a uma gestão de sua correspondência vis-à-vis sua não intencionalidade em que eles fossem encaminhados a algum arquivo como explicitado em sua carta-testamento endereçada à sua irmã. Uma marca do arquivo privado de Georges Duby diz respeito ao fato de que somente sua correspondência profissional foi preservada, não havendo a presença de vestígios de suas relações pessoais e/ou familiares, marca de um historiador que, apesar de ter praticado história da vida privada, não expôs sua própria esfera privada, ao contrário, concebeu-a como refúgio (BRANDI, 20I3, p. IOI-I30). Em contraste com o caso Duby, no Fundo Alice Piffer Canabrava tem-se a presença de correspondência endereçada à sua irmã e à sua mãe. Nesse sentido, seu Fundo dá a entrever um sujeito muito além da profissão historiadora. Como afirmei acima, ela figura como historiadora, professora, irmã, amiga, colega, orientadora...

$\mathrm{O}$ fato de Alice ter determinado a destruição de seus papéis pode denotar um outro sentido para seu autoarquivamento, para além de uma preocupação em forjar uma memória de si e sobre si para a posteridade. Por isso, faz-se mister atentar para o caráter social de seu arquivo ${ }^{26}$.

Alice Canabrava não exerceu funções públicas; não escreveu em jornais; não se manifestou publicamente sobre questões nacionais. A noção clássica de intelectual

24 Os últimos apontamentos de Philippe Artières (2013, p. 45-54) sobre o procedimento de arquivar a própria vida me inspiraram nessa reflexão. $\mathrm{O}$ ato de arquivar-se é tomado como uma arte, em que não são os atos e acontecimentos da vida valorizados, mas sim o ato de arquivá-los.

25 Felipe Brandi, ao tomar o arquivo pessoal do medievalista francês Georges Duby como fonte para sua tese de doutoramento acerca da prática historiográfica desse historiador, não deixa de refletir sobre esse arquivo enquanto objeto. Para tanto, ressalta a singularidade desse arquivo pessoal: é um arquivo pessoal de historiador. E aponta algumas questões para reflexão: “I) os arquivos de historiadores trazem o selo de atividade intelectual a que se entregam, em contraste com os de especialistas de outras disciplinas? Ou, ainda: 2) por sua prática e seu longo contato com os arquivos, está o historiador mais aplicado na conservação de sua documentação privada?" (BRANDI, 20I3, p. I20).

26 Miguel Soares Palmeira empreende algumas reflexões sobre seu trabalho com os Finley Papers, arquivo pessoal do historiador estadunidense radicado em Cambridge, Moses I. Finley, a partir de um exercício de história intelectual que mobiliza essa documentação com o fito de perscrutar os textos publicados; o processo de consagração de um modelo de história antiga e a trajetória de Finley (PALMEIRA, 2018). Apesar de seu trabalho ser com $o$ e não sobre $o$ arquivo de Finley, um imperativo apontado pelo historiador diz respeito a conhecer o material com o qual se trabalha para não reproduzir o senso comum em relação à vida intelectual. Ademais, aponta para a necessidade de tomar os arquivos pessoais em seu caráter social e extrair deles as devidas consequências, para além de um arquivamento da própria vida como forjamento de uma memória de si e sobre si (PALMEIRA, 20I3, p. 80-99). 
não lhe cabe. Ela, para mim, é um dos primeiros frutos da profissionalização do ofício de historiador na universidade. Canabrava é uma professora e pesquisadora stricto sensu. É uma acadêmica. Posiciona-se politicamente apenas nas cartas aos seus amigos Francisco Iglésias e Antônio Emílio Muniz Barreto. Sua única aparição pública se dá nos anos I980, quando é protagonista de uma reportagem em que é representada como "Professora do Delfim, do Pastore, do Viacava...”, que ocupavam importantes postos na gestão da política econômica nacional. O caráter social de seu arquivo pessoal, portanto, se liga à estruturação de uma rede estritamente acadêmica de professores e pesquisadores de história, a Apuh (depois de I97I, Anpuh), bem como ao IEB/USP e à FEA/USP. Seu arquivo permite vislumbrar os (des)caminhos pelos quais se estruturou a comunidade profissional de historiadores no Brasil.

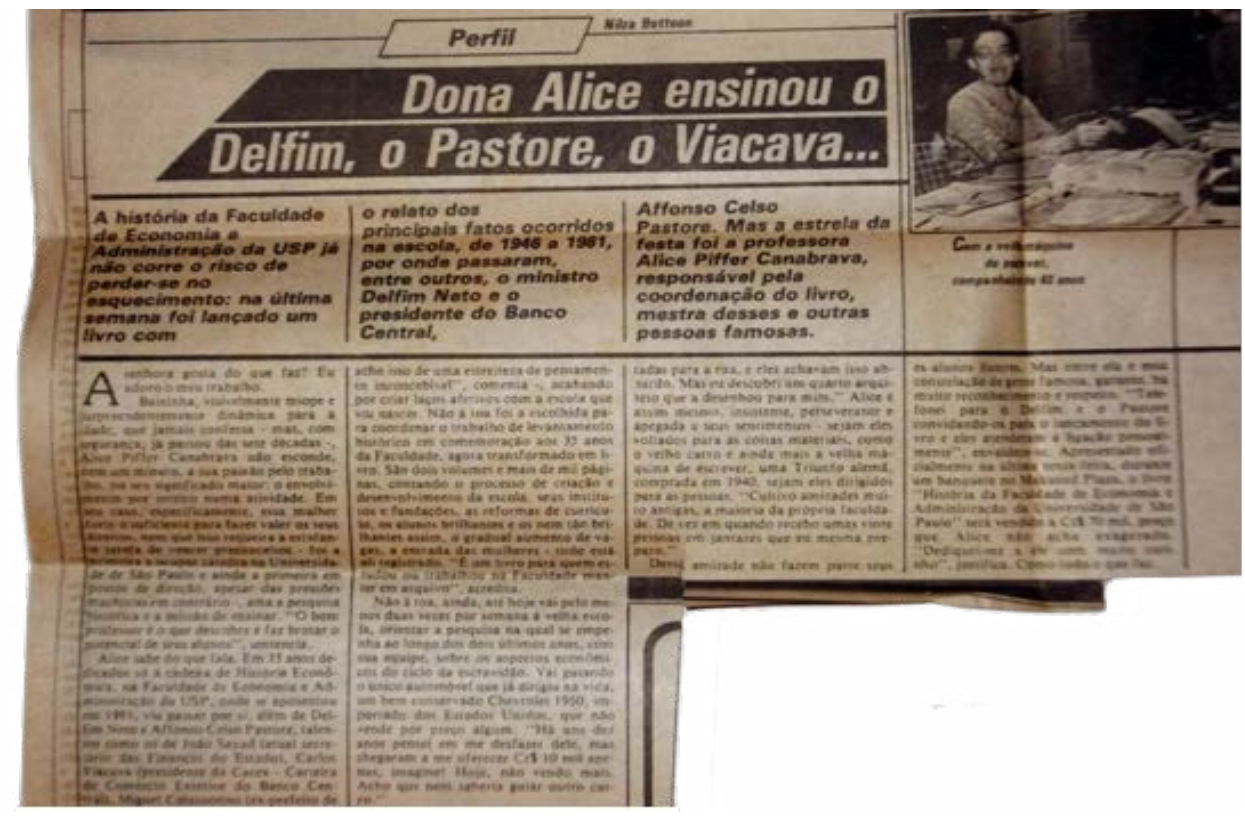

Figura 9-Reportagem em jornal desconhecido de autoria de Nilze Botteon, publicado em São Paulo, 2I de outubro de I984. Fundo Alice Piffer Canabrava, Arquivo IEB/USP

Do ponto de vista das práticas de arquivamento, no caso de Alice P. Canabrava, me chamou a atenção o fato de que muitas das cartas remetidas possuem cópias feitas com papel-carbono. Qual sua intenção ao adotar esse procedimento? A presença de cópias é mais intensa entre seus principais correspondentes: Francisco Iglésias, Maria Celestina Teixeira Mendes Torres, Antônio Emílio Muniz Barreto e Zélia Maria Cardoso de Mello. A primeira cópia feita com papel-carbono de carta, constante na primeira doação, remetida por ela a Iglésias, possui data inferida em I98I (uma vez que a historiadora menciona que está aposentada, mas que continuará por mais um ano na FEA/USP para concluir sua pesquisa sobre escravidão financiada pela Finep). Trata-se, na verdade, de um fragmento, pois se inicia na página três (CANABRAVA, I98Ib). Pode-se supor que as cópias das cartas remetidas a Iglésias a partir de I98I 
sirvam para que Alice saiba a data da última escrita e também para cobrar a ausência do amigo quando este demora a respondê-la. Há indícios de que ela desenvolveu um sistema de registro de correspondências em que anota a carta recebida e a resposta remetida. Desse sistema, deriva a necessidade de ter cópias das cartas remetidas.

Uma constante na correspondência com seus próximos é a cobrança em relação à ausência epistolar. Por exemplo, em cópia feita com papel-carbono de carta com o logotipo da FEA/USP datada de 26 de setembro de I983, Canabrava cobra notícias de Iglésias.

Cabe aqui o velho refrão: se Maomé não vai à montanha, a montanha vai a Maomé! Prometeu escrever-me, esvaiu-se o tempo, andei sondando a rua à espera do carteiro: nada. Tantos meses sem uma palavra sua, quando o longo silêncio foi rompido por seu telefonema. E eu estava magoada, muito magoada. Pensei muitas vezes: será que meu amigo Iglésias - meu único amigo, nem sequer se interessa em saber o que me aconteceu? Será que nossa velha amizade se prende ao esquema convencional da carta que chega e resposta que vai? (CANABRAVA, I983).

Não é diferente em relação à sua amiga de graduação, Maria Celestina Teixeira Mendes Torres. Em cópia feita com papel-carbono de carta remetida em 26 de janeiro de I986, Alice Canabrava queixa-se da ausência da amiga e a questiona sobre sua lide com a correspondência:

Há muito tempo não tenho cartas suas. Fico pensando por que não escreve. Seria que tem um registro de "carta vem, resposta vai”? Se tem, não deveria ser assim. Escrever cartas é como conversar com amigas, à distância, um bate papo cordial, sempre bem-vindo, independentemente de ter sido provocado ou não. (CANABRAVA, I986).

As cópias de cartas remetidas, além de ter a função de um sistema de registros das correspondências recebidas e de respostas enviadas, também funcionam para retomada de assuntos e para remissões. Em cópia de carta remetida a Antônio Emílio Muniz Barreto em 29 de dezembro de I983, a historiadora dá notícias da equipe de história econômica da FEA/USP e remete Muniz Barreto à carta anterior:

O Nelson H. Nozoe passou brilhantemente no concurso de doutorado: Io com louvor, por unanimidade. Ele estava muito nervoso nos dias que antecederam à defesa, mas, na hora, estava calmo, firme nas respostas. Eu fiquei muito contente. É mais um da equipe que avança na carreira.

Como lhe disse na carta anterior, Flávio se prepara para um ano em França, deverá partir em fevereiro. Ibrahin está trabalhando com o Pastore, no Banco Central, em Brasília. Luna, na Secretaria da Fazenda, com o Sayad. Iraci, firme nas pesquisas. Tomás Aquino, pouco vejo. Zélia, trabalhando como sempre. E todos sempre sentindo falta de você. (CANABRAVA, 1983-grifos meus).

Por fim, o fato de parte da correspondência ativa de Alice Canabrava ter sido por ela copiada facilita o trabalho do pesquisador, uma vez que, dentre seus principais 
correspondentes, somente parte do espólio de Francisco Iglésias se encontra em instituição de custódia, no caso, o Instituto Moreira Salles do Rio de Janeiro.

\section{Algumas palavras finais}

As reflexões empreendidas na segunda parte deste artigo não teriam sido possíveis sem um convívio quase diário, por dois anos, com a documentação remanescente de Alice Piffer Canabrava. Tive a satisfação de intermediar a doação entre a família e a instituição. Um percurso, perpassado/atravessado pelo afeto, iniciado com os primeiros contatos com a sobrinha-neta de Canabrava, Lúcia Carvalho, que me recebeu em sua casa, onde guardava os papéis de sua "tia Alice”. Após animadas conversas e partilhas de memórias sobre sua tia, Lúcia decidiu que o IEB deveria ser o lugar para a guarda dessa documentação. No dia da doação, Lúcia foi presenteada pela então chefe do Arquivo, Elisabete Marin Ribas, com lindas flores.

A partir desse momento se iniciou todo um trabalho de separação da documentação e agrupamento em tipos documentais, com o fito de ter uma radiografia dela. Depois da formulação do quadro de arranjo, o trabalho de descrição documental, por unidade. Por dois anos, um convívio quase diário com os "restos mortais" de Alice. Foi esse convívio cotidiano - a leitura e descrição de cada documento - que me sensibilizou a empreender as reflexões da segunda parte deste artigo. Sem ele, a reflexão seria outra.

Ao expor os procedimentos de organização do Fundo Alice Piffer Canabrava, pretendo estimular historiadores e historiadoras a realizarem esse tipo de trabalho, que, além de disponibilizar o acervo para consulta de pesquisadores e interessados em bens culturais em geral, possui um potencial reflexivo ímpar.

Ademais, dar publicidade a esse fundo significa empenhar-se na mitigação das assimetrias de gênero, tão presentes na vida intelectual brasileira e que também perpassam a formação e a divulgação dos arquivos pessoais. Dos 45 arquivos pessoais do Instituto, apenas I3 são de mulheres: Alice Piffer Canabrava; Anita Malfatti; Aracy Amaral; Aracy Guimarães Rosa; Lupe Cotrim; Maria Abreu; Marlyse Meyer; Marta Rossetti Batista; Odette de Barros Mott; Oneyda Alvarenga; Tarsila do Amaral; Veridiana Prado; Yolanda Mohalyi (SIMIONI; ELEUTÉRIO, 20I8, p. 2I). Nesse sentido, o I Seminário Internacional Arquivos, Mulheres e Memórias, realizado nos dias 2I, 22 e 24 de março de $20 I 7$ no IEB e entre 28 e 3I do mesmo mês no Centro de Pesquisa e Formação do Sesc, constituiu esforço ímpar nesse sentido, somado à posterior publicação de alguns trabalhos em dossiê na Revista do Instituto de Estudos Brasileiros (2018). 


\section{SOBRE O AUTOR}

OTÁVIO ERBERELI JÚNIOR é pós-doutorando no

Instituto de Estudos Brasileiros da Universidade de

São Paulo (IEB/USP).

oerberelijr@usp.br

https://orcid.org/0000-0002-3180-34I8

\section{REFERÊNCIAS}

ARTIÈRES, Philippe. Arquivar-se: a propósito de certas práticas de autoarquivamento. In: TRAVANCAS, Isabel; ROUCHOU, Joëlle; HEYMANN, Luciana. Arquivos pessoais: reflexões multidisciplinares e experiências de pesquisa. Rio de Janeiro: FGV, 20I3, p. 45-54.

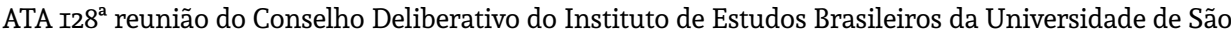
Paulo. In: Processo 2003.I.59.3I.o. Arquivo IEB. Fundo IEB.

BELLOTTO, Heloísa Liberalli. Sistemática do arranjo. In: BELLOTTO, Heloísa Liberalli. Arquivos permanentes: tratamento documental. 4. ed. Rio de Janeiro: FGV, $2007 \mathrm{a}$.

BELLOTTO, Heloísa Liberalli. O sentido da descrição documental. In: BELLOTTO, Heloísa Liberalli. Arquivos permanentes: tratamento documental. 4 ed. Rio de Janeiro: FGV, $2007 \mathrm{~b}$.

BELLOTTO, Heloísa Liberalli. Identificação de fundos. In: BELLOTTO, Heloísa Liberalli. Arquivos permanentes: tratamento documental. 4. ed. Rio de Janeiro: FGV, 2007c.

BENTHIEN, Rafael Faraco. Interdisciplinaridades: latinistas, helenistas e sociólogos em revistas (França, I898-I920). 367 f. Tese (Doutorado em História Social), Faculdade de Filosofia, Letras e Ciências Humanas, Universidade de São Paulo, 20II.

BENTHIEN, Rafael Faraco. O que há de impessoal em arquivos pessoais: considerações a partir de uma experiência de pesquisa na França. Vozes, Pretérito e Devir, v. 3, 20I4, p. 42-57.

BRANDI, Felipe. Arquivos privados e história dos historiadores: sobrevoo no acervo pessoal de Georges Duby. In: TRAVANCAS, Isabel; ROUCHOU, Joëlle; HEYMANN, Luciana. Arquivos pessoais: reflexões multidisciplinares e experiências de pesquisa. Rio de Janeiro: FGV, 20I3, p. IOI-I30.

CALDEIRA, João Ricardo de Castro. IEB: origem e significados. São Paulo: Oficina do livro Rubens Borba de Moraes, Imprensa oficial do Estado, 2002.

CAMARGO, Ana Maria de; GOULART, Silvana. Tempo e circunstância: a abordagem contextual dos arquivos pessoais. São Paulo: IFHC, 2007.

CANABRAVA, Alice Piffer. (I942). O comércio português no Rio da Prata (I580-I640). São Paulo: Faculdade de Filosofia, Ciências e Letras. Boletim XXXV. História da Civilização Americana. n. 2, I944.

CANABRAVA, Alice Piffer. Carta a Francisco Iglésias. São Paulo, 22 out. I972. Acervo Francisco Iglésias. IMS/RJ. FI-C-CP (IOO).

CANABRAVA, Alice Piffer. Testamento, I973. Acervo pessoal de Lúcia Carvalho.

CANABRAVA, Alice Piffer. (I944). A indústria do açúcar nas ilhas inglesas e francesas do mar das Antilhas, I697-I755. Tese (Doutorado). São Paulo: Universidade de São Paulo, I98I.

CANABRAVA, Alice Piffer. Entrevista. Projeto Estudos Brasileiros. MIS/SP, I98Ia. 00035EBRoo026AD (Estudos brasileiros rolo II6.27 A-OI50). 
CANABRAVA, Alice Piffer. Carta a Francisco Iglésias. São Paulo, I98Ib. Fundo Alice Piffer Canabrava. Arquivo IEB/USP. APC-CP-PI, I3(5).

CANABRAVA, Alice Piffer. (I946). O açúcar nas Antilhas (I697-I755). 2. ed. São Paulo: Instituto de Pesquisas Econômicas, I98Ic. (Ensaios Econômicos, I5).

CANABRAVA, Alice Piffer. Carta a Francisco Iglésias. São Paulo, I7 nov. I98Id. Fundo Alice Piffer Canabrava. Arquivo IEB/USP. APC-CP-PI, 27-(2).

CANABRAVA, Alice Piffer. Carta a Francisco Iglésias. São Paulo, 29 abr. 1982. Fundo Alice Piffer Canabrava. Arquivo IEB/USP. APC-Ca-P2, II-(5).

CANABRAVA, Alice Piffer. Carta a Francisco Iglésias. São Paulo, 26 set. I983a. Fundo Alice Piffer Canabrava. Arquivo IEB/USP. APC-CA,P2, I3-(2).

CANABRAVA, Alice Piffer. Carta a Antonio Emilio Muniz Barreto. São Paulo, 29 dez. I983b. Fundo Alice Piffer Canabrava. Arquivo IEB/USP. APC-CA-P4, I5-(2).

CANABRAVA, Alice Piffer. Carta a Maria Celestina Teixeira Mendes Torres. São Paulo, 26 de jan. I986. Fundo Alice Piffer Canabrava. Arquivo IEB/USP. APC-TORR-oo6.

CANABRAVA, Alice Piffer. Minhas reminiscências. Economia Aplicada, São Paulo, v. I, n. I, p. I57-I63, I997.

CANABRAVA, Alice Piffer. O desenvolvimento da cultura do algodão na Província de São Paulo (I86I-I875). 3. ed. São Paulo: Edusp/Anpuh, $20 I I$.

CERTEAU, Michel de. Heterologies: discourse on the other. Minneapolis: University of Minnesota Press, 2010.

CERTEAU, Michel de. A operação historiográfica. In: CERTEAU, Michel de. A escrita da história. 3. ed. Rio de Janeiro: Forense, 20II, p. 45-זII.

CERTEAU, Michel de. História e estrutura. In: CERTEAU, Michel de. História e psicanálise: entre ciência e ficção. 2. ed. Belo Horizonte: Autêntica, 20I2a, p. I63-I78.

CERTEAU, Michel de. O ausente da história. In: CERTEAU, Michel de. História e psicanálise: entre ciência e ficção. 2. ed. Belo Horizonte: Autêntica, 20I2b, p. I79-I88.

CERTEAU, Michel de. História e psicanálise: entre ciência e ficção. Belo Horizonte: Autêntica, 20I2c.

CERTEAU, Michel de. Fazer com: usos e táticas. In: CERTEAU, Michel de. A invenção do cotidiano: artes de fazer. 22. ed. Petrópolis: Vozes, 20I4, p. 86-Ioo.

COLÓQUIO Michel de Certeau [em Uso. Artes, Saberes e Antropologia (ASA), Departamento de Antropologia da FFLCH/USP, I9 e 2I setembro de 20I6. Disponível em: http://www.coletivoasa.dreamhosters. com/coloquio-michel-de-certeau-em-uso. Acesso em: jul. 202I

ERBERELI JÚNIOR, Otávio. A Faculdade de Ciências Econômicas e Administrativas da Universidade de São Paulo e a escrita da história econômica de Alice Piffer Canabrava. História Econômica eł História de Empresas. São Paulo, v. I9, n. I, 20I6a, p. 9-40.

ERBERELI JÚNIOR, Otávio. De preterida a preferida: considerações em torno da trajetória intelectual de Alice Piffer Canabrava (I935-I95I). História da Historiografia, Ouro Preto, n. 22, 20I6b, p. 97-II5.

ERBERELI JÚNIOR, Otávio. A trajetória intelectual de Alice Piffer Canabrava: um ofício como sacerdócio (I935-I997). Tese (Doutorado em Ciências). Programa de Pós-Graduação em História Econômica, Faculdade de Filosofia, Letras e Ciências Humanas, Universidade de São Paulo, 2019.

ERBERELI JÚNIOR, Otávio. A trajetória intelectual de Alice Piffer Canabrava: um ofício como sacerdócio (I935-I997). Mariana: SBTHH, 202I.

IEB/USP. Guia do IEB. Instituto de Estudos Brasileiros da Universidade de São Paulo, 20Io. Disponível em: http://www.ieb.usp.br/guia-ieb-2/. Acesso em: 7 jul. 202I.

I SEMINÁRIO Internacional Arquivos, Mulheres e Memórias. Programação. Disponível em: http:// 
www.ieb.usp.br/wp-content/uploads/sites/I27/20I7/03/I-Semin\%C3\%AIrio-Internacional-Arquivos -Mulheres-e-Mem\%C3\%B3rias.pdf. Acesso em: jul. 202I.

LOPEZ, André Porto Ancona. Como descrever documentos de arquivo: elaboração de instrumentos de pesquisa. São Paulo: Arquivo do Estado/Imprensa Oficial, 2002.

MCKEMMISH, Sue. Evidence of me. Archives and Manuscripts, n. 24, v. I, I996, p. 28-45.

MCKEMMISH, Sue. Provas de mim... Novas considerações. In: TRAVANCAS, Isabel; ROUCHOU, Joëlle; HEYMANN, Luciana. Arquivos pessoais: reflexões multidisciplinares e experiências de pesquisa. Rio de Janeiro: FGV, 20I3, p. I7-43.

PALMEIRA, Miguel Soares. Arquivos pessoais e história da história: a propósito dos Finley Papers. In: TRAVANCAS, Isabel; ROUCHOU, Joëlle; HEYMANN, Luciana. Arquivos pessoais: reflexões multidisciplinares e experiências de pesquisa. Rio de Janeiro: FGV, 20I3, p. 80-99.

PALMEIRA, Miguel Soares. Moses Finley e a "economia antiga": a produção social de uma inovação historiográfica. São Paulo: Intermeios, 2018.

RICOEUR, Paul. A memória, a história, o esquecimento. Campinas: Editora da Unicamp, 2007.

RIEB - Revista do Instituto de Estudos Brasileiros. Dossiê Mulheres, Arquivos e Memórias, n. 7I, dez. 2018. Disponível em: https://www.revistas.usp.br/rieb/issue/view/I0898. Acesso em: jul. 202I.

SANTOS, Alessandra Soares. Francisco Iglésias: a história e o historiador. São Paulo: Alameda, 2017. SIMIONI, Ana Paula Cavalcanti; ELEUTÉRIO, Maria de Lourdes. Mulheres, arquivos e memórias. Revista do Instituto de Estudos Brasileiros, Brasil, n. 7I, 20I8, p. I9-27.

SIRINELLI, Jean-François. Os intelectuais. In: RÉMOND, René (org.). Por uma história política. 2. ed. Rio de Janeiro: FGV, 2003, p. 23I-269.

SWIFT, Graham. Ever after. London: Picador, I992. 